\section{Ikke egnet i norsk kardiologi}

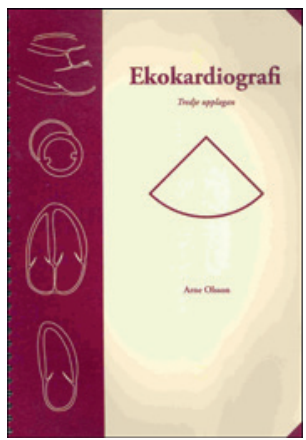

\section{Arne Olsson \\ Ekokardiografi}

3. utg. 103 s, tab, ill. Stockholm:

TrycksakSpecialisten, 2010. Pris SEK 498

ISBN 978-91-633-7284-1
Som kardiolog, med mange års erfaring innen klinisk ekkokardiografi, får jeg et inntrykk av at boken er skrevet av og for kliniske fysiologer. De grunnleggende prinsippene og hemodynamiske betraktningene er velskrevne og instruktive. Dessverre mangler det en god del praktiske tips som kan være gode å ha for en nybegynner, bl.a. hvilke problemer man kan møte når man skal få gode registreringer, og hvordan man prøver å løse dette i praksis. Eksempelvis leser vi på s. 38 om «kammarfunksjon»: «I apikal fyrrumsvy och apikal tvårumsvy ritas en linje längs endokardiet i slutdiastole» osv. Det henvises til ideelle tegninger av de to snittene, og saken skulle være grei. For oss som har levd med denne metoden i over 20 år, og forsøkt å lære opp andre kolleger, er det på ingen måte så enkelt. Dessverre finnes det ingen bilder av hvordan man egentlig har målt dette i praksis, og heller ikke noen omtale av de feilene man kan gjøre. Eksempler på gale målinger kunne også ha vært på sin plass.

Boken er altfor mye preget av gode, men forenklede tegninger av strukturer som slett ikke er så lette å fremstille som tegningene kan gi inntrykk av. En kontroversiell måling er diameter av venstre ventrikkels utløpstrakt, målt med todimensjonal ekko som ledd i å beregne arealet til en aortastenose. I boken er en slik diameter kun gjengitt med en tegning. Jeg savner skikkelige ekkobilder som tydelig kunne illustrere hvilke utfordringer dette innebærer, både ved native klaffer og hos ventilopererte. Noen betraktninger om hvilken betydning denne diameteren har, burde avgjort foreligge i en slik lærebok.

Forholdet mellom tegninger og ekkobilder er omtrent 4:1, hvilket anses som en stor svakhet. Spesielt er viktige områder som å identifisere intrakardiale tromber og bakterielle vegetasjoner, bare sporadisk berørt. Her er det mange skjær i sjøen. Transøsofageal ekkokardiografi er stemoderlig omtalt på 20 linjer. Aktuelle snitt som bør fremstilles med en slik undersøkelse, er kun gjengitt som noen få tegninger i den prinsipielle omtalen. I rettferdighetens navn må jeg nevne at det er tre fine bilder av transøsofageal ekkokardiografi fra spesielle kasus senere.

Vi finner dessverre kun tre linjer om tredimensjonal ekko med bare et bilde av en mitralklaff. Jeg savner både en bredere omtale av teknikken og ikke minst noen betraktninger om den potensielle tilleggsinformasjonen som vi kan fă, ved å inkludere tredimensjonal ekko etter å ha utført en tradisjonell todimensjonal ekkoundersøkelse.

Det er 19 tabeller, stort sett med referanseverdier. Spesielt verdifulle er ventildataene. Problemet er bare at alle disse tabellene også er gjengitt bakerst. I tillegg til alle tegningene og en haug med formler blir dermed boken nokså omfattende og rotete. Legg til at målinger av dimensjon og funksjon av de fire hjertekamrene kommer litt her og der. Eksempelvis omtales høyre ventrikkels dimensjoner som måling av diametre på s. 24, og den systoliske funksjonen med bl.a. arealfraksjon på s. 47. Noen ord om at vi da stort sett beregner innløpstraktus, og ikke hele høyre ventrikkel i apikale snitt, kunne også vært med.

Man har brukt tabellene til American Society of Echocardiography (ASE) fra 2005 for referanser til venstre ventrikkels dimensjoner og kontraktilitet. Forfatterne av ASE-tabellene gjør det helt klart at disse dataene er basert på upubliserte undersøkelser av 510 normalvektige, ikke-diabetiske hvite, afroamerikanere og amerikanske indianere uten kjent kardiovaskulær sykdom. Hvor representative kan disse være for den populasjonen vi møter i norske sykehus? Metodikken for de endimensjonale referansene i tabell 3 er ikke rapportert. Slik tabellen nå fremstår, sammen med tegningene i figurene 2-14, får man inntrykk av at de er avledet fra todimensjonal ekko. Tradisjonelt i Norge har man alltid utført slike målinger med M-mode. Men dette blir ikke klargjort verken i retningslinjene fra ASE eller i Ekokardiografi.

Et viktig referansepunkt er den nedre normalgrensen for venstre ventrikkels ejeksjonsfraksjon. I boken er den angitt til $55 \%$, bedømt med todimensjonal ekko (metoden fremgår heller ikke her, men trolig dreier det seg om biplan Simpson, tabell 7). Siden de fleste av oss i Norge bruker en grense på $50 \%$ (ev. ned til $45 \%$ ), burde det vært påpekt at referansen til ASE ikke er basert på grenseverdi i en normalpopulasjon, men på konsensus blant eksperter og kjent risiko.

Omtalen av diastolisk dysfunksjon er uhyre komplisert, med massevis av variabler å holde styr på. Dette var moderne rundt årtusenskiftet og er nå blitt sterkt forenklet, noe forfatteren ikke har tatt hensyn til.

Summa summarum er ikke dette en bok jeg vil anbefale i undervisningen av dem som skal tilegne seg denne teknikken i dagens norske kardiologiske praksis. Derimot må den være bra for kliniske fysiologer med sans for diverse matematiske formler, ultralydens grunnprinsipper og hemodynamiske betraktninger.

\section{Jan Erik Otterstad}

Hjertemedisinsk avdeling

Sykehuset i Vestfold

Tønsberg 